\title{
The Role of Democratic Governance and Indirect Expropriation in International Investment Treaty Violations ${ }^{*}$
}

\author{
Jeffrey Ziegler ${ }^{\dagger}$ and David Carlson ${ }^{\ddagger}$
}

May 8, 2020

\begin{abstract}
Democracies are thought to violate treaties less frequently than non-democracies, yet democracies violate bilateral investment treaties (BITs) just as often as non-democracies. Though democratic governments may intend to meet their international obligations, and though democratic institutions provide greater political constraints to encourage compliance, investment agreements may conflict with the goal of maintaining domestic public support. Specifically, we argue that credible elections create strong incentives for governments to side with domestic voters over foreign business interests, and to pass legislation that violates investment agreements. We use a data set of BIT violation complaints that better captures potential indirect expropriation to confirm prior findings that show a difference in violations by regime type. Since policies are not passed immediately and companies do not file arbitration complaints instantly when a potential violation occurs, democratic governments are only more likely to be sued as their time in office increases. The results suggest that the ability of voters to sanction leaders is an important mechanism that incentivizes governments to pass legislation that potentially violates investment treaties through indirect expropriation.
\end{abstract}

Keywords: investment treaties, electoral accountability, indirect expropriation, political economy

\footnotetext{
${ }^{*}$ We would like to thank Michael Bechtel and Guillermo Rosas for helpful comments, as well as Michael Igyarto for suggestions regarding data collection.

†Post-Doctoral Fellow, Emory University, Institute for Quantitative Theory and Methods, Atlanta, GA 30322, United States, e-mail: jeffrey.ziegler@emory.edu .

† Assistant Professor, Koç University, Department of International Relations, Istanbul, Turkey, e-mail: dcarlson@ku.edu.tr.
} 
Democracies are viewed as favorable treaty partners, and there is a fairly accepted consensus that democracies violate international investment treaties less than non-democracies (Gaubatz 1996; Rickard 2010). Democracies should limit expropriation risk of foreign investments by constraining executive power and reducing investment uncertainty (Jensen 2008; Weymouth 2011). This expectation is partially confirmed empirically; we see in the left panel of Figure 1 that democracies are more likely to sign international investment treaties, such as bilateral investment treaties (BITs). The right panel of Figure 1, however, demonstrates that democracies are just as likely to be a defendant in investor-state arbitration. Why do democracies sign more investment agreements if they just as likely as non-democracies to violate those agreements?

We suggest that this paradox is driven by the various motivations that states have to protect

Figure 1: Signatures and violations of bilateral investments treaty (BIT) as a proportion of all BITs in force by regime type from 1995 to 2013.
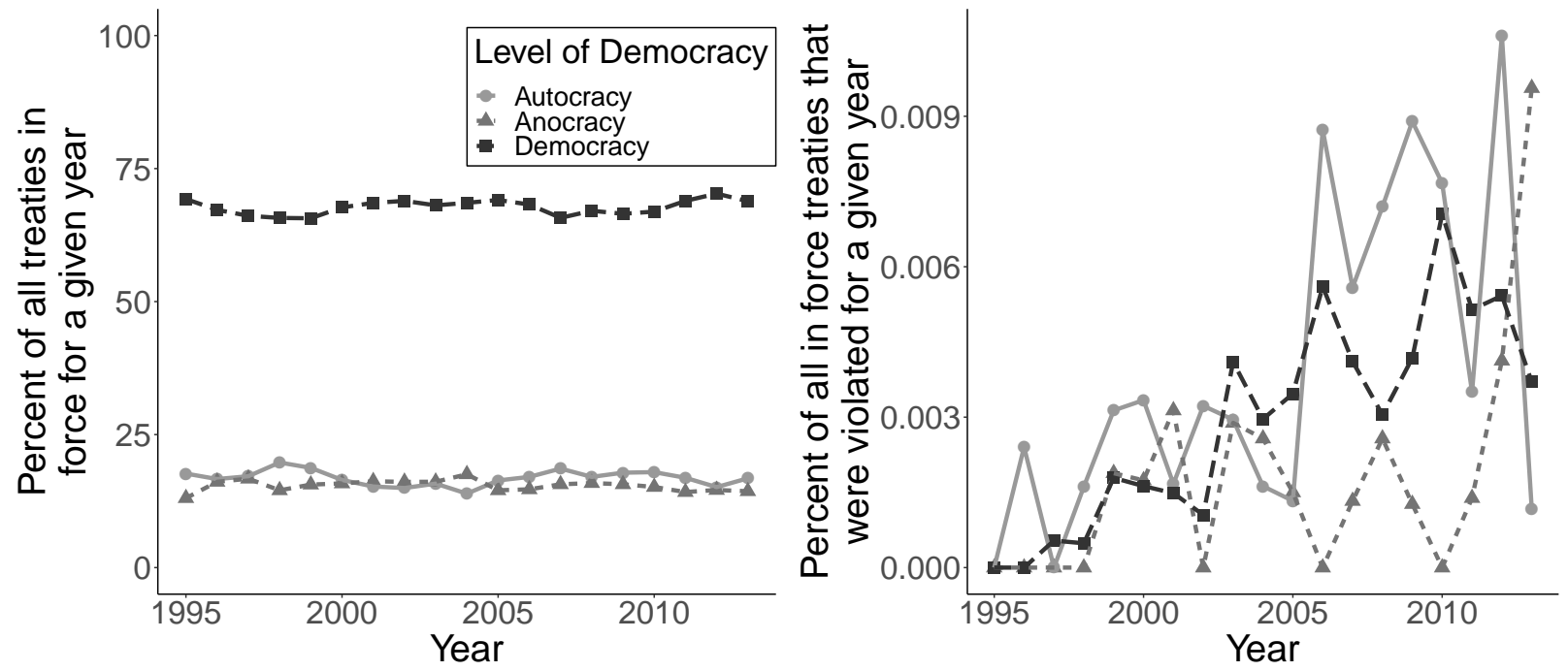

Notes: The bilateral investment treaty data comes from the Investor-State Law Guide, which records public filing regarding bilateral investment treaty arbitration, for instance, with the International Centre for Settlement of Investment Dispute (ICSID). The left panel plots the percentage of bilateral treaties that are in force in each year by regime type. For each treaty signed, there are two signatories. The right panel displays the number of treaty violations in each year. If, for instance, there were only one treaty in our data set and one of the two signatories violated the treaty once, the percent of all in force treaties that were violated would equal 0.5. Multiple violations can be filed for one investment agreement in one year. We provide a similar figure in the Online Appendix with the raw number of violations and new BITs signed by regime type and year. 
investors, encourage future investment, discourage capital flight, but most importantly maintain domestic political support. For example, the Spanish company Técnicas Medioambientales Tecmed, S.A. owned a site for the containment and treatment of hazardous waste near the Mexican town of Hermosillo. This investment was protected under the Mexico-Spain BIT. The facility caused massive public uproar in 1997, and the public organized sit-ins to prevent trucks carrying the hazardous waste from entering the facility (Schefer 2020). Local opponents challenged the site's technical viability, the lack of public participation in decisions regarding the facility, and the facility's proximity to the town. Because of the public controversy, the Mexican government refused to reissue the license for the site in November 1998, and Tecmed formally claimed that this was equivalent to expropriation and in breach of the Mexico-Spain BIT. Tecmed filed suit in the summer of 2000, and after a draining arbitration, the Spanish investor was awarded \$5 million on May 2003 (Peterson 2003). Public pressure to act in favor of local domestic interests, at the peak of Mexico's democratic transition, impacted the Mexican government's decision to violate the international investment treaty.

Because citizens can credibly hold government leaders accountable through democratic elections, we argue there is a systematic difference in the propensity of democracies and nondemocracies to pass legislation that potentially breaches investment treaties. We suggest that democracies are more likely to violate investment treaties, purposefully or not, because democratic elections pressure politicians to represent the broad interests of citizens. Therefore, we hypothesize that democratic governments will appear more likely to violate investment treaties as their time in office increases because they are more likely to pass legislation that may infringe on investment agreements.

We test our theory using data from the Investor-State Law Guide to measure perceived bilateral investment treaty violations. These public filings provide a better measure of potential treaty violations than other measures to date, including international arbitration, because they capture perceived violations that never make it to court, as well as violations that are disputed in $a d$ hoc 
tribunals. We show that democracies, on average, are more likely than non-democracies to be perceived as BIT violators. In particular, we derive an explicit functional form that demonstrates that the empirical relationship is strictly driven by the delayed effect of legislation that governments pass that cumulatively increases the risk of violating investment treaties. Importantly, our findings are robust to arbitration cases that are (1) eventually filed in court and (2) filed in venues other than ICSID, such as the International Chamber of Commerce (ICC) and Stockholm Chamber of Commerce (SCC) from the Investor-State Dispute Settlement (ISDS) database (Wellhausen 2016).

The theoretical and empirical implications of this article qualify the widely held belief that democracies are less likely to violate international obligations that they have accepted, primarily due to their defining characteristics: broad governance and credible elections. We purposefully do not, however, advocate for regime type as a primary explanation of investment treaty violations. We argue, instead, that the credibility of elections and delayed implications of policies that appeal to a broader base are important sub-components of democracy that are worth studying. We hope our theory and empirical evidence spur future work that can more precisely test the relationship between the cycle of credible elections and indirect expropriation of foreign investment.

\section{Incentives for Democracies to Sign and Violate BITs}

Signing a BIT is often interpreted as a signal to the international investment community. It is largely assumed that states are in competition to attract foreign investment, so BITs offer an opportunity for states to increase their credibility by protecting international investors from the potential policies of the state in which these investments are made through dispute settlement mechanism (DSMs) (Allee and Peinhardt 2010; Simmons 2010). Though there is mixed evidence that these treaties actually promote FDI, there is stronger evidence that states sign them with 
the intent to promote international investment (Yackee 2008). ${ }^{2}$ BITs may be thought of as a bargain between political actors and business interests. Both parties know that harmful policy to business interests may need to be passed in the future. Acknowledging this, governments are not necessarily tying their hands per se; they are agreeing to pay damages to business interests if such policies are passed. And democratic governments are likely aware of their potential to pass legalisation in the future that violate agreements because democracies push for more carve outs in treaty obligations (Blake 2013).

The notion that democracies have greater incentives to violate BITs stands in contrast to the common assumption that democracies are inherent treaty-compliers due to greater political constraints (Jensen 2008; Jensen et al. 2012). We agree that an important reason for why democracies have traditionally been thought of as treaty compliers is that as the number of "veto players" increases, the propensity of a government to directly seize assets that violate an investment treaty should theoretically decrease. Democratic governments, however, can still violate investment agreements in different ways. For instance, Graham, Johnston and Kingsley (2018) show domestic political constraints reduce the likelihood of direct expropriation, but these political restraints do not impact governments' propensity to engage in transfer restrictions of investment agreements, which are often a sub-component of BITs.

In fact, the vast majority of disputes in contemporary investment litigation do not arise from the direct seizure of assets or establishment of discriminatory taxation, but rather these indirect expropriations (Pelc 2017). ${ }^{3}$ Since expropriation causes the government to incur a cost, violations are most often the result of policy concessions. Indirect expropriation occurs when a state passes policy or regulation that harms the earning potential of a firm or industry. The most common instances of indirect expropriation involve environmental regulation, public health regulation,

\footnotetext{
${ }^{2}$ Many investment treaties may not actually lead to foreign investment in certain industries (Kerner and Lawrence 2014), so governments may not have consequential opportunities to expropriate. Thus, we include trade flows as a percent of GDP in the empirical analysis.

${ }^{3}$ Investment disputes in the 19th and early 20th century were the result of direct seizure of private assets by autocratic governments and/or insurgents. By the mid-20th century, expropriation was primarily caused by the nationalization of assets after colonial liberation. Modern investment disputes now center around regulatory regimes and foreign firms (Sornarajah 2017).
} 
and public policy concessions (Gaukrodger and Gordon 2012). ${ }^{4}$

We acknowledge and expect that democracies are far more likely to have the regulatory regimes that produce policies in these areas and to produce the types of policies that lead to disputes, even if they do not necessarily view their regulatory actions as "violations." Given that indirect expropriations are largely unintentional, we contend violations are a function of the heterogeneity and types of interests represented in a polity as a whole. Undoubtedly, democratic governments are necessarily representative of more heterogeneous interests because policymakers must be responsive to numerous intersecting, dynamic preferences. ${ }^{5}$ Since an investment treaty is inherently rigid and might often be at odds with democratic decision-making (Schneiderman 2008), the longer a democratic government is in power and has opportunities to enact its preferred policies, it is reasonable to expect that it is more likely to be a violator. Our central argument suggests that BITs provide differing incentives, largely due to the occurrence of elections, to pass potentially expropriating regulation. Legislation is not enacted immediately, and the impact of policies is not instantly realized, so democratic governments' propensity to violate investment treaties increases as a function of their electoral term.

It may, however, be the case that democracies are not persistent violators, rather democracies are attractive targets of indirect expropriation arbitration. There is a strategic logic to which suits are brought, and suits targeting democracies, though they are much less successful, may attempt to induce regulatory chill rather than to win the actual case (Pelc 2017). Unfortunately, it is impossible with the available data to distinguish between the motivations of investors to file claims, the validity of those claims, and legitimate violations. Nonetheless, even if democracies are targeted in an attempt to limit future regulation, we argue that arbitration initiation against

\footnotetext{
${ }^{4}$ Though, there is some debate in international law regarding when and which regulatory policies constitute expropriation (Newcombe 2005).

${ }^{5} \mathrm{We}$ do not necessarily believe democratically elected legislators react to domestic citizens that have preferences over FDI regulatory policies, rather citizens care about regulatory policies that frequently involve FDI. In other words, we do not argue that democratic populations know or care about investment policy and support expropriation. Rather, we believe that citizens in democracies have a wider set of preferences that inherently encourages governments to pass legislation that may result in indirect expropriation.
} 
democracies is unlikely to explain any effect of national legislative and executive elections due to the great uncertainty, costs, and time associated with litigation. Therefore, if a relationship exists between level of democracy and violations, it is improbable that it is due to a latent increase in the incentives to file complaints against democratic governments the longer they stay in power given the uncertainty in arbitration duration.

Our principal expectation is that democracies are more likely to violate an investment treaty than non-democracies precisely because the political pressure within democracies is more likely to be felt when voters are able to hold leaders accountable. Other sources of potential violation, such as wealth extraction, unintentional violations, or elite-motivated policy concessions, are unlikely to differ between regime types. If there is a conflict between the public's preferences and an existing investment agreement, we hypothesize that a democratic government is more likely to violate the treaty to appease the public because political leaders stand for election and this effect is cumulative.

\section{Data and Analytic Strategy}

Limiting the bilateral investment treaty filings to one per case from 1990 through 2013 results in 280 unique cases. The final data includes over 75,000 bilateral investment treaty-years among 178 countries, with each treaty-year in the data twice for both potential dyadic violations. For example, the United States and Bolivia signed a bilateral investment treaty in 1998. The United States as a potential violator of this treaty is in the data 15 times, one for each year, and Bolivia as a potential violator 15 times. ${ }^{6}$ Finally, the sample of BITs that are included in the analysis only contain the state-pairs that are required to publicly file.

The data includes arbitration proceedings, but also include complaints, intents, and other sig-

\footnotetext{
${ }^{6}$ We do not model any dyadic or intra-country dependence because we do not have any strong theoretical justification to estimate fixed-effects (or clustered standard errors) at the country, dyad, or directed-dyad level. Further, given that there are over 60 countries and 400 unique dyads, this strategy reduces the effective number of observations and would likely artificially inflate the standard errors.
} 
nals of bilateral investment treaty violations that never make it to court or are argued in front of an ad hoc tribunal. This minimizes some of the bias of using arbitration as a proxy for treaty violation, however, not all violations are challenged and not all challenges are violations. We discuss in the the next sub-section how we account for these shortcomings in the data, but we argue that measuring potential violations is most appropriate to model trends in indirect expropriation. Our outcome variable, therefore, is whether any perceived violations occurred by a contracting state in any given year. We estimate logistic regression models because the fully specified model would allow the categories to increase without a bound, as the number of violations is potentially infinite, but there are no observations above four. ${ }^{7}$

The first predictor of interest is a potential violator's level of democracy, which we measure using the combined Polity IV score (Marshall, Gurr and Jaggers 2017). A testable implication of our theory is that the marginal effect of electoral terms is smaller, or potentially not distinguishable from zero, for less democratic regimes. As such, we include an interaction between the time until the next national election and a potential violator's level of democracy. We anticipate that the estimated coefficient of a potential violator's level of democracy will be increasingly positive as a government's time in office increases. Since the log odds of the logit are already nonlinear, this may be enough to capture the underlying relationship. Nevertheless, we use both a continuous and trichotomous measure of democracy based on the Polity regime type thresholds (autocracy [-10 to -6], anocracy [-5 to 5], democracy [6 to 10]).

To measure electoral terms, we take advantage of the National Elections Across Democracy and Autocracy (NELDA) data set because the data includes any national executive or legislative election (e.g., parliament, legislature, constituent assembly), regardless of competitiveness, fairness, or legitimacy (Hyde and Marinov 2012). If democracies pass legislation that is more likely

\footnotetext{
${ }^{7}$ We acknowledge that the number of BIT violations relative to treaty-year dyads is rare, such that only about $0.33 \%$ of potential violations occurred. To specifically address the excess of zeroes in the outcome we also consider rare events logistic and zeroinflated negative binomial logistic regression models in the Online Appendix. We additionally analyze the outcome as a count, as well as ordered categories in the Online Appendix by estimating negative binomial logistic and ordered logistic regression models. The models in the manuscript do not differ substantively or statistically from those models estimated in the Online Appendix.
} 
to violate BITs, the propensity to violate an agreement should increase as government duration and level of democracy increase. We are able to test this further implication of our theory by examining all national elections, even for non-democratic governments.

We additionally consider other variables that may be causally prior to a potential violator's level of democracy and the likelihood of a treaty violation. These include the log of GDP (purchasing power parity), the annual change in GDP (PPP), the percentage of GDP accounting for trade, and the percentage of GDP accounting for natural resource rents available from the World Bank's World Development Indicators. Further, given that foreign direct investment flows differentially into signatory states by regime type, we include the net inflows of FDI as a percentage of GDP. It may also be the case that it is not the timing of constraints (elections), but the intensity of political institutional constraints that explains the propensity of democracies to violate treaties. As such, we include a commonly employed measure of political institutional constraints from the Political Constraints Index Dataset (Henisz 2002). ${ }^{8}$ This is not an exhaustive set of potential predictors of BIT violations, but we contend that these variables account for theoretically meaningful differences in economic conditions across regime types that might affect violation rates, which provides a better estimate of whether democratic governance has a direct association with the propensity of a state to violate an investment treaty. ${ }^{9}$

Four regression models constitute the main analysis. The first regression utilizes all the relevant theoretical predictors, including a continuous measure for level of democracy, while excluding the time until the next election. The second regression uses the same set of predictors, but the level of democracy is a factor representing whether a government is an autocracy (-10 to -6

\footnotetext{
${ }^{8}$ It is likely that the constraints placed on leaders leading up to (by other democratic or judicial institutions) and during elections (due to the fairness of the electoral process and increased competition) are greater in democracies. Yet, this relationship is unlikely to be altered by the marginal effect of government duration or election timing. In other words, although greater political constraints may decrease the ability of a government to violate an investment agreement, the effect of political constraints should not impact the occurrence of democratic elections, nor their effect (if one exists) on the propensity of governments to violate an investment agreement. Therefore, this variable is included as an additive term in our analyses.

${ }^{9}$ In analyses not shown, the length of time a treaty has been in place was also included as a control. Outdated treaties are likely a source of potential violation. The estimate was reliable and substantively significant, but did not change the reliability of the polity estimate and had only very minor impacts on the magnitude of the polity estimate. Because the duration of one BIT is unlikely causally prior to levels of democracy, it has been omitted.
} 
on the Polity scale), anocracy (-5 to 5), or democracy (6 to 10). The last two regression models include an interaction between the level of democracy (for each measure) and the time until the next election, as well as all the relevant covariates.

\section{Accounting for Government Duration and Selection into BITs}

A central concern of our research design is our ability to accurately measure the timing of potential violations in relation to governmental terms (i.e., elections). As such, we do our best to use the contemporaneous value of all predictors in the primary analysis. It is not possible, however, to disaggregate the temporal nature of the data from the treaty-year to treaty-quarter or treaty-month. Unfortunately, the scarce information and data provided in BIT filings is not only a limitation of our data, but is a constraint irrespective of data source.

The lag structure, therefore, is selected based on the empirical patterns of BIT violations. In most instances, the offense usually occurred at some point in the time range of zero to four years before the filing or publication of documents. We acknowledge that when we observe a complaint, we do not know when the actual violation occurred; we simply observe and measure the complaint, which could be years after the decision to violate was made. Further, we cannot track complaints that are dropped after an election to investigate whether frivolous complaints are filed to damage domestic governments prior to election. Still, if litigants strategically time complaints, we account for this by also conducting additional analyses with one, two, and three year lags. The results in the Online Appendix support the approach taken in the manuscript and indicate that regime type only impacts a government's propensity to violate as their electoral term comes to an end.

Additionally, there are selection processes that may make democracies more likely to appear as targets of arbitration that may be unrelated to our argument about democracy and elections. Countries are not randomly selected into BITs and the criteria for self-selection into treaties may be associated with regime type. Estimating a model of treaty violation without first estimating 
an equation of whether a country is a BIT signatory could lead bias our results. We estimate Heckman selection models, therefore, in the Online Appendix because one may suspect the processes of deciding to violate an investment treaty and signing a BIT in a given arbitration forum are related (Heckman 1976). The results, in fact, more strongly suggest that the marginal effect credible elections is conditional on government shifts and vice versa.

A further limitation of our data is that we largely capture potential violations lodged by ICSID signatories, but not all violations are filed in venues such as ICSID. This is potentially more problematic as states increasingly turn to other courts for arbitration. Yet, approximately $75 \%$ of complaints within our data are registered with ICSID, which is comparable to other ISDS sources on arbitration (approximately 65\% of arbitration cases in the Wellhausen (2016) dataset are filed through ICSID). This should alleviate some concerns that our data does not capture disputes that would appear in alternative venues. Nevertheless, we conduct the same analysis using the Wellhausen (2016) dataset to further estimate the likelihood that an arbitration case is actually filed since the data only represent those arbitrations that were formally registered. We report in the Online Appendix that our findings are robust to (1) an alternative measurement of the outcome (potential violations versus filed cases), and (2) alternative arbitration regimes, not only ICSID.

We cannot, moreover, know if potential violations are real violations, though we do not assume that complaints by foreign investors are always legitimate. Even if there are many complaints and arbitration cases against democracies, that does not necessarily mean that democracies are breaking their treaty commitments. As such, we estimate in the Online Appendix whether a violation is successfully litigated with the ISDS data. We find that democracies are less likely to win cases that have been filed against them, suggesting that potential violations are a good indicator of real violations and not merely a measure of firms greater gained understanding of investor-state dispute mechanisms to challenge unwanted policy changes in democracies with cases of declining merit (Pelc 2017). 


\section{Results}

The estimated coefficient for level of democracy is positive and statistically reliable across all specifications, including both the continuous and factor operationalizations. ${ }^{10}$ Importantly, the level of democracy is positive and reliable in the two models that include an interaction with governmental terms, which suggests that during an election year (when time until election $=0$ ) a government is more likely to have a complaint lodged against it as the level of democracy increases. The exponentiated coefficient estimates, or odds ratios, from the interaction model reveal that a one unit increase in the continuous Polity score during an election year is associated with a change in the odds ratio of over 1.05 (2.5\% and $97.5 \%$ confidence intervals: $1.01,1.08)$. This, however, understates the non-linear relationship between the credibility of elections, government shifts, and investment treaty violations.

To demonstrate, Figure 2 highlights the marginal effect of the level of democracy and time until the next election on the predicted probability that a given country violates a treaty. First, we calculate the marginal effect of election timing on the probability of violation while varying the polity score in the left panel. For instance, the marginal effect given a shift from the beginning of a typical four year term (newly elected, -4 years away from election) to the midterm (-2 years away from election) results in a $0.001[0.0008,0.001])$ increased probability of violation. This is a relatively large increase in the likelihood of violating a bilateral treaty considering that the probability a full democracy $($ Polity $=10)$ has any violations in a given year is 0.00097 . The effect increases even more as a typical four year term comes to an end, such that full democracies have a $0.0013[0.0006,0.002])$ greater probability of violating a treaty in the year leading up to an election (-1 year away to election year). Though the marginal effect appears to be small, the probability that a democracy will violate a treaty during an election year compared to an average year is approximately 1.34 times greater.

\footnotetext{
${ }^{10}$ The full estimates and analysis of covariates for the logistic regression models are presented in Table A.1 in the Online Appendix.
} 
Figure 2: Change in the predicted probability of violation given the interaction between the continuous measure of democracy and time until election.
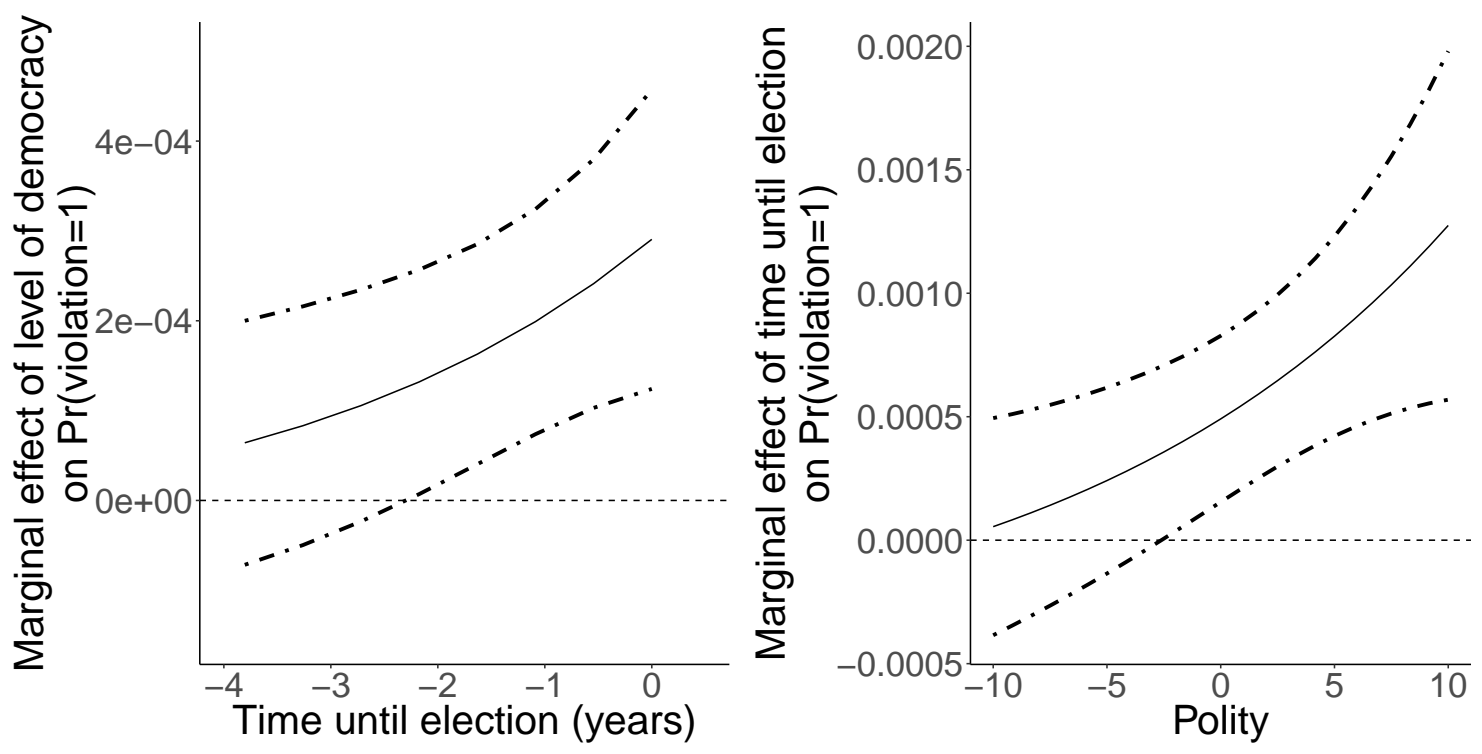

Notes: We cannot estimate the marginal effect as $\hat{\delta}_{1}=\hat{\beta}_{1}+\hat{\beta}_{3} x_{2}$ because the size of $\hat{\delta}_{1}$ does not convey any intuitive interpretation of the size of the effect of a given moderating variable. Therefore, we estimate the change in the predicted probability, $\hat{y}$, given a shift in the moderator, while also varying $x_{2}$ (plotted along the $\mathrm{x}$-axis). $95 \%$ confidence intervals are shown.

We also consider the effect of elections on autocracies (Polity $=-3$ ), which is the first quartile of the pooled sample. We find no discernible impact on the probability of violating a BIT. The marginal effect on the likelihood of violating a BIT given a shift from the beginning of a four year term to the year of election is not statistically differentiable from zero $(0.001[-0.00005,0.002])$. This intuition is also displayed in the right panel of Figure 2, which shows that the occurrence of elections only impacts the probability of violation when elections are increasingly credible and democratic. This evidence supports our theory that when elections lack credibility and are not democratic, we would not expect a positive relationship between the electoral cycle, the level of democracy, and a government's potential to violate an investment agreement.

As a further illustration of this phenomenon, consider the case of Venezuela, a state notorious for expropriations of foreign investment. Throughout most of the analyzed time period Venezuela was not considered a democracy, and it violated 10 treaties. The Venezuelan government has, for 
example, serviced their sovereign debt crisis by using the state run oil company (PDVSA) to expropriate foreign assets (e.g., Conoco-Philips), despite widespread calls for them to default to alleviate domestic economic suffering (Taylor 2019).

For comparison, nearest neighbor matching on our covariates determines Argentina to be a very similar state, except with respect to level of democracy and number of treaties violated. Argentina was a democracy for the entire time period, and yet, Argentina violated three times the number of treaties (30) than did Venezuela. In response to their own financial crisis and currency devaluation, the Argentine government conversely enacted policies to help citizens and businesses, which increased the likelihood of indirect expropriation and investment arbitration (Perez-Aznar 2017). ${ }^{11}$

We consider this a very telling example because Venezuela is known as a frequent violator, but its democratic counterpart violated many more treaties. Interestingly, Argentina had seven presidential and parliamentary elections from 1990 to 2013, while Venezuela had six national elections during the same period. Although both countries held nearly the same number of elections, we suggest that the pressure on governments to pass potentially expropriating legislation caused by credible elections may explain why the two countries differed so dramatically in their propensity to violate bilateral investment treaties.

\section{Discussion}

The central contribution of our analysis is that a state's level of democracy, because political leaders stand for credible elections, impacts the propensity of a state to violate an international investment treaty. Our theory and evidence is inline with a growing literature on authoritarian regimes, FDI, and BITs that asserts autocrats are better treaty compliers because the positive (and possibly negative) economic effects of BITs are largest in autocracies (Arias, Hollyer and

\footnotetext{
${ }^{11}$ Argentina lost a large portion of its cases (approximately $62 \%$ in comparison to the cross-country average $45.8 \%$ ), meaning the arbitration tribunals ruled that Argentina did violate its investment treaties more often than not when they were sued.
} 
Rosendorff 2018). Leaders, elected or not, stay in office more easily and longer when the economy is doing well, so autocrats that do not face credible elections, have a strong incentive to not violate BITs to maintain strong sovereign credit (DiGiuseppe and Shea 2016). Our argument compliments this logic; elected leaders that face credible exits from office are more likely to side with their domestic voters and pass legislation that may lead to indirect expropriation and treaty violation. We believe this is a topic that is academically, practically, and normatively interesting. Academically, scholars should consider which types of investment agreements are more likely to conflict with the general interests of the public, and whether those agreements are more likely to be violated. Practically, investors may want to consider this research in making investment decisions, and governments may want to consider this when anticipating future costs and benefits of treaty design. Normatively, if democratic states are signing investment treaties to appease business interests, knowing they will likely have to pay damages in the future, they are essentially subsidizing business with taxes without any, or almost any, awareness by the general public. 


\section{References}

Allee, Todd and Clint Peinhardt. 2010. "Delegating differences: Bilateral investment treaties and bargaining over dispute resolution provisions." International Studies Quarterly 54(1):1-26.

Arias, Eric, James R. Hollyer and B. Peter Rosendorff. 2018. "Cooperative Autocracies: Leader Survival, Creditworthiness, and Bilateral Investment Treaties." American fournal of Political Science 62(4):905-921.

Blake, Daniel J. 2013. "Thinking ahead: government time horizons and the legalization of international investment agreements." International Organization 67(4):797-827.

DiGiuseppe, Matthew and Patrick E. Shea. 2016. "Borrowed time: Sovereign finance, regime type, and leader survival." Economics \& Politics 28(3):342-367.

Gaubatz, Kurt Taylor. 1996. “Democratic states and commitment in international relations.” International Organization 50(1):109-139.

Gaukrodger, David and Kathryn Gordon. 2012. "Investor-state dispute settlement: A scoping paper for the investment policy community." OECD Working Papers on International Investment (3).

Graham, Benjamin A.T., Noel P. Johnston and Allison F. Kingsley. 2018. "Even Constrained Governments Take: The Domestic Politics of Transfer and Expropriation Risks.” fournal of Conflict Resolution 62(8):1784-1813.

Heckman, James J. 1976. The common structure of statistical models of truncation, sample selection and limited dependent variables and a simple estimator for such models. In Annals of Economic and Social Measurement. NBER pp. 475-492.

Henisz, Witold J. 2002. “The political constraint index (POLCON) dataset.”.

Hyde, Susan D. and Nikolay Marinov. 2012. "Which elections can be lost?" Political Analysis 20(2):191-210.

ICTSD. 2010. “Tobacco Company Files Claim against Uruguay over Labelling Laws.”. [Online; posted 10-March-2010].

IFC. 2009. "Stabilization Clauses and Human Rights.” 
Jensen, Nathan. 2008. "Political risk, democratic institutions, and foreign direct investment." The Journal of Politics 70(4):1040-1052.

Jensen, Nathan, Glen Biglaiser, Quan Li, Edmund Malesky, Pablo Pinto and Joseph Staats. 2012. Politics and foreign direct investment. University of Michigan Press.

Kerner, Andrew and Jane Lawrence. 2014. "What's the risk? Bilateral investment treaties, political risk and fixed capital accumulation.” British fournal of Political Science 44(1):107-121.

Marshall, Monty G., Ted Robert Gurr and Keith Jaggers. 2017. "Polity IV project: Political regime characteristics and transitions, 1800-2016." Center for Systemic Peace .

Newcombe, Andrew. 2005. "The boundaries of regulatory expropriation in international law." ICSID review 20(1):1-57.

Pelc, Krzysztof J. 2017. “What Explains the Low Success Rate of Investor-State Disputes?” International Organization 71(3):559-583.

Perez-Aznar, Facundo. 2017. "The Recent Argentina-Qatar BIT and the Challenges of Investment Negotiations." Investment Treaty News. [Online; posted 12-June-2017].

Peterson, Luke Eric. 2003. “International Treaty News: Mexico’s Treatment of Hazardous Waste Site Violates Mexico-Spain BIT.”.

Rickard, Stephanie J. 2010. "Democratic differences: Electoral institutions and compliance with GATT/WTO agreements.” European fournal of International Relations 16(4):711-729.

Schefer, Krista Nadakavukaren. 2020. International investment law: text, cases and materials. Edward Elgar Publishing.

Schneiderman, David. 2008. Constitutionalizing economic globalization: Investment rules and democracy's promise. Cambridge University Press.

Simmons, Beth. 2010. "Treaty compliance and violation." Annual Review of Political Science $13: 273-296$.

Sornarajah, Muthucumaraswamy. 2017. The international law on foreign investment. Cambridge University Press.

Taylor, Adam. 2019. "How Citgo, a U.S. oil company, became Venezuela's lifeline." Washington Post. [Online; posted 29-January-2019]. 
Wellhausen, Rachel L. 2016. "Recent trends in investor-state dispute settlement." fournal of International Dispute Settlement 7(1):117-135.

Weymouth, Stephen. 2011. "Political institutions and property rights: veto players and foreign exchange commitments in 127 countries." Comparative Political Studies 44(2):211-240.

Yackee, Jason Webb. 2008. "Bilateral Investment Treaties, Credible Commitment, and the Rule of (International) Law: Do BITs Promote Foreign Direct Investment?” Law \& Society Review 42(4):805-832. 


\section{Online Appendix}

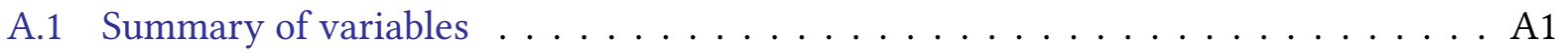

A.2 Robustness of Main Analysis . . . . . . . . . . . . . . . . . A A1

A.2.1 Alternative Logistic Regression Models . . . . . . . . . . . . . . . . . . A3

A.2.2 Heckman Selection Models . . . . . . . . . . . . . . . . . . . . . A4

A.2.3 Alternative Investor-Dispute Data . . . . . . . . . . . . . . A5

A.2.4 Assessing and Addressing Missingness . . . . . . . . . . . . . . A6

A.3 Tables and Figures for Online Appendix . . . . . . . . . . . . . . . A7

In addition to the models presented in the manuscript, we provide a number of alternative modeling strategies to more precisely estimate how the relationship between credible democratic elections and investment treaty violation. The Online Appendix includes summaries of the variables used in the analyses, the extended results of the main analysis, as well as several robustness checks of the main analysis to various sub-sampling procedures, and modeling techniques.

\section{A.1 Summary of variables}

For a greater description of all our predictors for BIT violations, each panel in Figure A.5 displays the distribution of each variable used in the manuscript's main analyses in Table A.1.

[Place Figure A.5 here.]

\section{A.2 Robustness of Main Analysis}

First, Table A.1 shows the full estimated coefficients of the main analysis presented in the manuscript. The variable of interest, level of democracy, is reliably and positively related to BIT violations in all models when time until election equals zero. As a robustness, since the 
regressions are complete-case analyses, we use sampling in the last subsection of the Appendix to confirm the results are not an artifact of using the full data set.

[Place Table A.1 here.]

To test whether the interaction between democracy and time until election is linear, we calculate binned estimates of the marginal effect of the moderator $(D=$ time until election) on $x=$ polity (corresponding to autocracy, anocracy, and democracy). We are primarily concerned with whether the interactive association is in the correct order (i.e. monotonically increasing or decreasing), whether we estimate the correct number of bins (pair-wise t-statistics for the binning estimates), and whether we can reject the linear multiplicative interaction model by comparing it with a more flexible model of multiple bins (Wald test). We estimate a linear model with violations as the outcome using interf lex in R (Hainmueller, Mummolo, and Xu 2018) to reject the null hypothesis of the Wald test that the linear interaction model and the three-bin model (autocracy, anocracy, and democracy) are statistically equivalent $(p \approx 0)$. This provides more evidence for a non-linear relationship between election timing and election quality on violations.

We also consider various lag structures based on the empirical patterns of BIT violations. Since most offenses usually occur between zero to five years before the filing or publication of documents, we conduct additional logistic regression models with one, two, and three year lags for all the covariates, except time until election, in case litigants strategically time complaints. The results shown in Table A.2 confirm that the contemporaneous values provide the best model fit, and most of the estimated coefficients for the time invariant variables stay the same, which further justifies our modeling choice in the manuscript. Moreover, the marginal effect of regime type is only reliable as elections near.

[Place Table A.2 here.] 


\section{A.2.1 Alternative Logistic Regression Models}

The first alternative modeling specification we utilize is a zero-inflated, or rare events, logistic regression "which helps produce unbiased estimates with greater precision" (King and Zeng 2001). Table A.3 shows that the variable of interest, level of democracy, is reliably and positively related to BIT violations in all models when time until election equals zero. The statistical reliability and the substantive interpretation of the results do not differ from the logistic regression results found in Table A.1.

\section{[Place Table A.3 here.]}

We also perform an ordinal logistic regression to capture whether democratic elections impact the magnitude of violations. Formally, the ordered logistic model is specified as $y^{*}=X^{\prime} \beta+\epsilon$, such that $y=0$ if $y^{*} \leq \mu_{1} ; 1$ if $\mu_{1}<y^{*} \leq \mu_{2} ; 2$ if $\mu_{2}<y^{*} \leq \mu_{3} ; 3$ if $\mu_{3}<y^{*} \leq \mu_{4} ; 4$ if $\mu_{4}<y^{*}$, and $y^{*}$ represents the latent variable that captures propensity to violate an investment treaty, and $y$ represents the observed outcome. Each $\mu$ captures the cut-off between categories, $X$ is the vector of covariates, and $\beta$ is the vector of coefficients. The exponential transformation, $\frac{\operatorname{Pr}\left(y_{i}>j\right)}{\operatorname{Pr}\left(y_{i} \leq j\right)}=e^{-\mu_{j}+y^{*}}$, translates to the proportional probability, or odds, of being above a particular category. The estimated coefficients of the ordinal logit are displayed in Table A.4, which show a similar story: democratic governance influences the propensity to violate more treaties as election time nears.

[Place Table A.4 here.]

The estimated coefficients of the negative binomial regression are found in Table A.5. We regress the count of BIT violations on the polity score and the binned measure of democracy, including the same relevant covariates mentioned in the manuscript. The estimated coefficients do not differ drastically from the other robustness models, nor from the logit estimates presented in the main analysis, which further validates our central finding that democracies are less likely to violate international investment obligations only when elections are proximate. 
[Place Table A.5 here.]

\section{A.2.2 Heckman Selection Models}

One of the possible selection processes that may make democracies more likely to appear as targets is that democracies are more likely to sign BITs, or be signatories to the ICSID convention in the first place, which is a necessary condition for being accused of a treaty violation. Therefore, we model the unobserved structural process of investment treaty violation such that $y_{i}^{S *}$ is the latent decision of selection for each country to be in a bilateral treaty agreement, $y_{i}^{S *}=\mathbf{x}_{i}^{S} \beta^{S^{\prime}}+\epsilon_{i}^{S}$. The latent outcome, $y_{i}^{O *}$, is the whether a violation occurred given that a treaty was in place, $y_{i}^{O *}=\mathbf{x}_{i}^{O} \beta^{O^{\prime}}+\epsilon_{i}^{O} \cdot \mathbf{x}_{i}^{S}$ and $\mathbf{x}_{i}^{O}$ are matrices of explanatory variables for the selection and outcome equation, though the explanatory variables are the same for both equations. We observe the outcome only if the latent decision to be in a bilateral treaty (when $y^{S *}$ is positive), as seen in Equation 1 and 2.

$$
\begin{aligned}
& y_{i}^{S}= \begin{cases}0 & \text { if } y_{i}^{S *}<0 \\
1 & \text { otherwise }\end{cases} \\
& y_{i}^{O}= \begin{cases}0 & \text { if } y_{i}^{S}=0 \\
y_{i}^{O *} & \text { otherwise }\end{cases}
\end{aligned}
$$

Table A.6 reports the results of the first stage selection equation (Equation 1) indicating whether any treaty was signed. Though somewhat difficult to interpret, the estimated coefficients indicate that democratic governments are less likely to sign BITs as their term continues, but they are significantly more likely to sign them at the beginning of their term (see Figure A.1). The estimates and substantive findings from the Equation 2 in Model 2 of Table A.6 do not differ substantially from the results presented in the manuscript in Table A.1.

[Place Figure A.1 here.] 
[Place Table A.6 here.]

\section{A.2.3 Alternative Investor-Dispute Data}

We have two primary concerns with our data on potential violations. First, we employ an alternate dataset from Wellhausen (2016) that contains "any public instance in which a foreign investor sues a sovereign state in an international tribunal. Thus, the database includes investment treaty arbitration, which is triggered by a treaty such as a Bilateral Investment Treaty (BIT), as well as other investment arbitrations brought under Investor-State Dispute Settlement (ISDS) based on contractual provisions or domestic rules" (Codebook Wellhausen 2016, 1). This helps alleviate concerns that our findings do not only apply to potential violations via ICSID, but also other arbitration venues.

Another benefit of the database is that it only includes arbitrations that are actually filed. "Thus, if a foreign investor offers a public notice of intent to file but does not actually file, it is not included. This distinction is clear when it comes to arbitrations filed at ICSID. It is less clear when arbitrations are filed at other less public venues" (2). This increases our ability to determine whether the data generating process for potential violations is relatively similar for cases that are eventually filed.

\section{[Place Table A.7 here.]}

The results, in fact, more strongly suggest that the marginal effect of the credibility of elections is conditional on the time to the next election. For instance, we can see that a similar pattern from Figure 2 in Figure A.2. Moreover, Table A.8 estimates the percent of cases that are actually

filed which are lost. The results from these models strengthens our argument that (1) potential violations may be a good indicator of actual violations, and (2) democratic governments are more likely to be sued as elections near.

[Place Figure A.2 here.] 
[Place Table A.8 here.]

\section{A.2.4 Assessing and Addressing Missingness}

We employ case-wise deletion in the manuscript, and retain approximately $90 \%$ of observations. Figures A.3 and A.4 display the missingness in our covariates for our time period of interest from 1990-2013. To address this missingness, we re-estimate each regression using a random subset of the data with the requirement that at least $95 \%$ of observations are complete cases. The results and interpretations do not differ from those presented in the primary analysis or Appendix.

[Place Figure A.3 and Figure A.4 here.]

To create samples that accurately represent the complete data set, we mimic the rarity of the outcome. Therefore, when we randomly subset approximately $10 \%$ of the full data set for each sample, we subset approximately 400 observations with a zero outcome. As such, the first model drops 24 observations, and the second and third drop 35 due to data unavailability. The low number of dropped cases relative to the size of the sample makes the concern for biased estimates fairly minimal. Each panel in Figure A.6 displays the distribution of each variable from the three randomly selected subsets used for the regression analyses in Table A.2.

[Place Figure A.5 here.]

Importantly, no sample differs dramatically with regards to outliers, and all samples match the overall empirical distribution of each variable in the total data set (seen in Figure A.5). Moreover, the results of regression models using the samples are statistically and reliable similar to those reported in Table A.2.

[Place Figure A.6 here.] 


\section{A.3 Tables and Figures for Online Appendix}

Table A.1: Extended logistic regression estimates from manuscript.

\begin{tabular}{|c|c|c|c|c|}
\hline & \multicolumn{4}{|c|}{ Dependent variable: } \\
\hline & \multicolumn{4}{|c|}{ Any violation $(0=\mathrm{No}, 1=$ violations $>0)$} \\
\hline & $(1)$ & $(2)$ & $(3)$ & $(4)$ \\
\hline Polity & $\begin{array}{l}0.033^{*} \\
(0.017)\end{array}$ & $\begin{array}{l}0.046^{*} \\
(0.018)\end{array}$ & & \\
\hline Anocracy & & & $\begin{array}{c}1.015^{* * *} \\
(0.280)\end{array}$ & $\begin{array}{l}0.735^{*} \\
(0.327)\end{array}$ \\
\hline Democracy & & & $\begin{array}{c}1.242^{* * *} \\
(0.304)\end{array}$ & $\begin{array}{c}1.349^{* * *} \\
(0.331)\end{array}$ \\
\hline Time until election & & $\begin{array}{c}0.195^{* *} \\
(0.065)\end{array}$ & & $\begin{array}{c}0.293 \\
(0.210)\end{array}$ \\
\hline Polity*Time until election & & $\begin{array}{c}0.017 \\
(0.009)\end{array}$ & & \\
\hline Anocracy ${ }^{*}$ Time until election & & & & $\begin{array}{c}-0.326 \\
(0.231)\end{array}$ \\
\hline Democracy ${ }^{\star}$ Time until election & & & & $\begin{array}{c}0.120 \\
(0.229)\end{array}$ \\
\hline Control variables & ------- & ------ & ------ & ------ \\
\hline Political constraints & $\begin{array}{l}-0.761 \\
(0.491)\end{array}$ & $\begin{array}{l}-0.780 \\
(0.490)\end{array}$ & $\begin{array}{c}-1.136^{*} \\
(0.461)\end{array}$ & $\begin{array}{c}-1.150^{*} \\
(0.464)\end{array}$ \\
\hline $\log (\mathrm{GDP})$ & $\begin{array}{c}-0.093^{* *} \\
(0.035)\end{array}$ & $\begin{array}{c}-0.107^{* *} \\
(0.036)\end{array}$ & $\begin{array}{l}-0.071 \\
(0.037)\end{array}$ & $\begin{array}{c}-0.085^{*} \\
(0.037)\end{array}$ \\
\hline$\Delta \mathrm{GDP}$ & $\begin{array}{c}0.020^{* *} \\
(0.007)\end{array}$ & $\begin{array}{c}0.019 * * \\
(0.007)\end{array}$ & $\begin{array}{l}0.016^{*} \\
(0.007)\end{array}$ & $\begin{array}{l}0.017^{*} \\
(0.007)\end{array}$ \\
\hline Trade (\% of GDP) & $\begin{array}{c}-0.005^{*} \\
(0.002)\end{array}$ & $\begin{array}{c}-0.005^{*} \\
(0.002)\end{array}$ & $\begin{array}{c}-0.005^{*} \\
(0.002)\end{array}$ & $\begin{array}{c}-0.006^{* *} \\
(0.002)\end{array}$ \\
\hline FDI, net inflows (\% of GDP) & $\begin{array}{c}0.001 \\
(0.009)\end{array}$ & $\begin{array}{c}0.001 \\
(0.009)\end{array}$ & $\begin{array}{c}0.001 \\
(0.009)\end{array}$ & $\begin{array}{c}0.001 \\
(0.009)\end{array}$ \\
\hline Natural resource rents (\% of GDP) & $\begin{array}{c}0.011 \\
(0.007)\end{array}$ & $\begin{array}{c}0.009 \\
(0.007)\end{array}$ & $\begin{array}{l}0.017^{*} \\
(0.007)\end{array}$ & $\begin{array}{l}0.017^{*} \\
(0.007)\end{array}$ \\
\hline Constant & $\begin{array}{c}-3.172^{* * *} \\
(0.925)\end{array}$ & $\begin{array}{c}-2.584^{* *} \\
(0.953)\end{array}$ & $\begin{array}{c}-4.513^{* * *} \\
(1.001)\end{array}$ & $\begin{array}{c}-3.880^{* * *} \\
(1.044)\end{array}$ \\
\hline AIC & 3014.593 & 2998.084 & 3000.918 & 2979.041 \\
\hline $\mathrm{BIC}$ & 3088.518 & 3090.490 & 3084.084 & 3089.929 \\
\hline Log Likelihood & -1499.297 & -1489.042 & -1491.459 & -1477.521 \\
\hline $\mathrm{N}$ & 76160 & 76160 & 76160 & 76160 \\
\hline
\end{tabular}

Notes: The outcome in each model is whether any violation occurred. Logistic regression coefficients shown with standard errors in parentheses in both models $\left({ }^{* * *} p<0.001,{ }^{* *} p<0.01,{ }^{*} p<0.05\right)$. In all models, the total number of potential treaty-year observations is 523,035 , though in 446,875 of those there is no BIT present, leaving a total of 76,160 potential violator-years. 
Table A.2: Logistic regression from manuscript with various lags for covariates.

\begin{tabular}{lcccc}
\hline \hline & \multicolumn{4}{c}{ Dependent variable: } \\
\cline { 2 - 5 } & $(1)$ & $(2)$ & $(3)$ & $(4)$ \\
& No lag & $\operatorname{Lag}_{t-1}$ & $\operatorname{Lag}_{t-2}$ & $\operatorname{Lag}_{t-3}$ \\
\hline Anocracy & $0.994^{* *}$ & $0.813^{*}$ & 0.552 & 0.451 \\
& $(0.338)$ & $(0.333)$ & $(0.331)$ & $(0.337)$ \\
Democracy & $1.571^{* * *}$ & $1.684^{* * *}$ & $1.399^{* * *}$ & $1.502^{* * *}$ \\
& $(0.340)$ & $(0.333)$ & $(0.317)$ & $(0.315)$ \\
Time until election & 0.237 & 0.349 & 0.142 & 0.163 \\
& $(0.203)$ & $(0.224)$ & $(0.155)$ & $(0.156)$ \\
Anocracy ${ }^{*}$ Time until election & -0.222 & -0.387 & -0.160 & -0.191 \\
& $(0.229)$ & $(0.245)$ & $(0.191)$ & $(0.196)$ \\
Democracy Time until election & 0.159 & 0.053 & 0.260 & 0.216 \\
& $(0.223)$ & $(0.241)$ & $(0.179)$ & $(0.179)$ \\
\hline Constant & $-4.501^{* * *}$ & $-3.813^{* * *}$ & $-3.381^{* *}$ & $-2.703^{*}$ \\
& $(1.113)$ & $(1.080)$ & $(1.059)$ & $(1.057)$ \\
\hline Control variables & $\checkmark$ & $\checkmark$ & $\checkmark$ & $\checkmark$ \\
\hline AIC & 2918.635 & 2917.346 & 2932.614 & 2925.328 \\
BIC & 3028.794 & 3027.506 & 3042.774 & 3035.488 \\
Log Likelihood & -1447.317 & -1446.673 & -1454.307 & -1450.664 \\
N & 71681 & 71681 & 71681 & 71681 \\
\hline \hline
\end{tabular}

Notes: The outcome in each model is whether any violation occurred. In each model, all the covariates (with the exception of the time until election) are lagged by the specified number of years $(0,1,2$, or 3$)$. Standard errors in parentheses in both models $\left({ }^{* *} p<0.001,{ }^{* *} p<0.01,{ }^{*} p<0.05\right)$. In all models, the sample used has no missing values for all the lags, which reduces the total number of potential treaty-year observations to 71,681 . 
Table A.3: Rare events logistic regression estimates.

\begin{tabular}{|c|c|c|c|c|}
\hline & \multicolumn{4}{|c|}{ Dependent variable: } \\
\hline & \multicolumn{4}{|c|}{ Any Violations } \\
\hline & $(1)$ & $(2)$ & (3) & $(4)$ \\
\hline Polity & $\begin{array}{l}0.033^{*} \\
(0.017)\end{array}$ & $\begin{array}{c}0.046^{* *} \\
(0.018)\end{array}$ & & \\
\hline Anocracy & & & $\begin{array}{c}1.010^{* * *} \\
(0.280)\end{array}$ & $\begin{array}{l}0.747^{*} \\
(0.327)\end{array}$ \\
\hline Democracy & & & $\begin{array}{c}1.226^{* * *} \\
(0.304)\end{array}$ & $\begin{array}{c}1.353 * * * \\
(0.331)\end{array}$ \\
\hline Time until election & & $\begin{array}{c}0.183^{* *} \\
(0.065)\end{array}$ & & $\begin{array}{c}0.226 \\
(0.210)\end{array}$ \\
\hline Polity*Time until election & & $\begin{array}{l}0.018^{*} \\
(0.009)\end{array}$ & & \\
\hline Anocracy*Time until election & & & & $\begin{array}{l}-0.269 \\
(0.231)\end{array}$ \\
\hline Democracy ${ }^{*}$ Time until election & & & & $\begin{array}{c}0.182 \\
(0.229)\end{array}$ \\
\hline Control variables & & & & \\
\hline Political constraints & $\begin{array}{c}-0.768 \\
(0.491)\end{array}$ & $\begin{array}{l}-0.791 \\
(0.490)\end{array}$ & $\begin{array}{c}-1.147^{*} \\
(0.461)\end{array}$ & $\begin{array}{c}-1.168^{*} \\
(0.464)\end{array}$ \\
\hline $\log (\mathrm{GDP})$ & $\begin{array}{c}-0.092^{* *} \\
(0.035)\end{array}$ & $\begin{array}{c}-0.105^{* *} \\
(0.036)\end{array}$ & $\begin{array}{c}-0.070 \\
(0.037)\end{array}$ & $\begin{array}{c}-0.083^{*} \\
(0.037)\end{array}$ \\
\hline$\Delta \mathrm{GDP}$ & $\begin{array}{c}0.021^{* *} \\
(0.007)\end{array}$ & $\begin{array}{c}0.021^{* *} \\
(0.007)\end{array}$ & $\begin{array}{c}0.018^{* *} \\
(0.007)\end{array}$ & $\begin{array}{c}0.018^{* *} \\
(0.007)\end{array}$ \\
\hline Trade (\% of GDP) & $\begin{array}{c}-0.005^{*} \\
(0.002)\end{array}$ & $\begin{array}{c}-0.005^{*} \\
(0.002)\end{array}$ & $\begin{array}{c}-0.005^{*} \\
(0.002)\end{array}$ & $\begin{array}{c}-0.006^{* *} \\
(0.002)\end{array}$ \\
\hline FDI, net inflows (\% of GDP) & $\begin{array}{c}0.004 \\
(0.009)\end{array}$ & $\begin{array}{c}0.005 \\
(0.009)\end{array}$ & $\begin{array}{c}0.005 \\
(0.009)\end{array}$ & $\begin{array}{c}0.005 \\
(0.009)\end{array}$ \\
\hline Natural resource rents ( $\%$ of GDP) & $\begin{array}{c}0.011 \\
(0.007)\end{array}$ & $\begin{array}{c}0.010 \\
(0.007)\end{array}$ & $\begin{array}{l}0.017^{*} \\
(0.007)\end{array}$ & $\begin{array}{l}0.017^{*} \\
(0.007)\end{array}$ \\
\hline Constant & $\begin{array}{c}-3.206^{* * *} \\
(0.925)\end{array}$ & $\begin{array}{c}-2.642^{* *} \\
(0.953)\end{array}$ & $\begin{array}{c}-4.537^{* * *} \\
(1.001)\end{array}$ & $\begin{array}{c}-3.936^{* * *} \\
(1.044)\end{array}$ \\
\hline $\mathrm{AIC}$ & 3014.593 & 2998.084 & 3000.918 & 2979.041 \\
\hline $\mathrm{BIC}$ & 3088.518 & 3090.490 & 3084.084 & 3089.929 \\
\hline Log Likelihood & -1499.297 & -1489.042 & -1491.459 & -1477.521 \\
\hline $\mathrm{N}$ & 76160 & 76160 & 76160 & 76160 \\
\hline
\end{tabular}

Notes: The outcome indicates whether any violations occurred $(0=$ no, $1=$ violations $>0)$. Standard errors are shown in parentheses $\left({ }^{* *} p<0.001,{ }^{* *} p<0.01,{ }^{*} p<0.05\right)$. In all models, the total number of potential treaty-year observations is 523,035 , though in 446,875 of those there is no BIT present, leaving a total of 76,160 potential violator-years. 
Table A.4: Ordered multinomial logistic regression estimates.

\begin{tabular}{|c|c|c|c|c|}
\hline & \multicolumn{4}{|c|}{ Dependent variable: } \\
\hline & \multicolumn{4}{|c|}{ Any Violations } \\
\hline & $(1)$ & $(2)$ & (3) & $(4)$ \\
\hline Polity & $\begin{array}{l}0.033^{*} \\
(0.017)\end{array}$ & $\begin{array}{l}0.046^{*} \\
(0.018)\end{array}$ & & \\
\hline Anocracy & & & $\begin{array}{c}1.015^{* * *} \\
(0.280)\end{array}$ & $\begin{array}{l}0.736^{*} \\
(0.327)\end{array}$ \\
\hline Democracy & & & $\begin{array}{c}1.242^{* * *} \\
(0.304)\end{array}$ & $\begin{array}{c}1.349 * * * \\
(0.331)\end{array}$ \\
\hline Time until election & & $\begin{array}{c}0.195^{* *} \\
(0.065)\end{array}$ & & $\begin{array}{c}0.293 \\
(0.210)\end{array}$ \\
\hline Polity ${ }^{*}$ Time until election & & $\begin{array}{c}0.017 \\
(0.009)\end{array}$ & & \\
\hline Anocracy*Time until election & & & & $\begin{array}{l}-0.326 \\
(0.231)\end{array}$ \\
\hline Democracy ${ }^{*}$ Time until election & & & & $\begin{array}{c}0.120 \\
(0.229)\end{array}$ \\
\hline Control variables & -1 & & & \\
\hline Political constraints & $\begin{array}{l}-0.761 \\
(0.491)\end{array}$ & $\begin{array}{l}-0.780 \\
(0.490)\end{array}$ & $\begin{array}{c}-1.135^{*} \\
(0.461)\end{array}$ & $\begin{array}{c}-1.150^{*} \\
(0.464)\end{array}$ \\
\hline $\log (\mathrm{GDP})$ & $\begin{array}{c}-0.093^{* *} \\
(0.035)\end{array}$ & $\begin{array}{c}-0.107^{* *} \\
(0.036)\end{array}$ & $\begin{array}{l}-0.071 \\
(0.037)\end{array}$ & $\begin{array}{c}-0.084^{*} \\
(0.037)\end{array}$ \\
\hline$\Delta \mathrm{GDP}$ & $\begin{array}{c}0.020^{* *} \\
(0.007)\end{array}$ & $\begin{array}{c}0.019 * * \\
(0.007)\end{array}$ & $\begin{array}{l}0.016^{*} \\
(0.007)\end{array}$ & $\begin{array}{l}0.017^{*} \\
(0.007)\end{array}$ \\
\hline Trade (\% of GDP) & $\begin{array}{c}-0.005^{*} \\
(0.002)\end{array}$ & $\begin{array}{c}-0.005^{*} \\
(0.002)\end{array}$ & $\begin{array}{c}-0.005^{*} \\
(0.002)\end{array}$ & $\begin{array}{c}-0.006^{* *} \\
(0.002)\end{array}$ \\
\hline FDI, net inflows (\% of GDP) & $\begin{array}{c}0.001 \\
(0.009)\end{array}$ & $\begin{array}{c}0.001 \\
(0.009)\end{array}$ & $\begin{array}{c}0.001 \\
(0.009)\end{array}$ & $\begin{array}{c}0.001 \\
(0.009)\end{array}$ \\
\hline Natural resource rents ( $\%$ of GDP) & $\begin{array}{c}0.011 \\
(0.007)\end{array}$ & $\begin{array}{c}0.009 \\
(0.007)\end{array}$ & $\begin{array}{l}0.017^{*} \\
(0.007)\end{array}$ & $\begin{array}{l}0.017^{*} \\
(0.007)\end{array}$ \\
\hline Constant & $\begin{array}{c}-3.206^{* * *} \\
(0.925)\end{array}$ & $\begin{array}{c}-2.642^{* *} \\
(0.953)\end{array}$ & $\begin{array}{c}-4.537^{* * *} \\
(1.001)\end{array}$ & $\begin{array}{c}-3.936^{* * *} \\
(1.044)\end{array}$ \\
\hline $\mathrm{AIC}$ & 3182.312 & 3165.796 & 3168.635 & 3146.763 \\
\hline $\mathrm{BIC}$ & 3283.958 & 3285.924 & 3279.522 & 3285.372 \\
\hline Log Likelihood & -1580.156 & -1569.898 & -1572.318 & -1558.382 \\
\hline $\mathrm{N}$ & 76160 & 76160 & 76160 & 76160 \\
\hline
\end{tabular}

Notes: The outcome indicates whether any violations occurred $(0=$ no, $1=$ violations $>0)$. Standard errors are shown in parentheses $\left({ }^{* *} p<0.001,{ }^{* *} p<0.01,{ }^{*} p<0.05\right)$. In all models, the total number of potential treaty-year observations is 523,035 , though in 446,875 of those there is no BIT present, leaving a total of 76,160 potential violator-years. 
Table A.5: Negative binomial regression estimates.

\begin{tabular}{|c|c|c|c|c|}
\hline & \multicolumn{4}{|c|}{ Dependent variable: } \\
\hline & \multicolumn{4}{|c|}{ Violations } \\
\hline & $(1)$ & $(2)$ & (3) & $(4)$ \\
\hline Polity & $\begin{array}{c}0.047^{* *} \\
(0.018)\end{array}$ & $\begin{array}{c}0.061^{* *} \\
(0.019)\end{array}$ & & \\
\hline Anocracy & & & $\begin{array}{c}1.279^{* * *} \\
(0.300)\end{array}$ & $\begin{array}{c}1.125^{* *} \\
(0.346)\end{array}$ \\
\hline Democracy & & & $\begin{array}{c}1.495^{* * *} \\
(0.326)\end{array}$ & $\begin{array}{c}1.662^{* * *} \\
(0.353)\end{array}$ \\
\hline Time until election & & $\begin{array}{c}0.203^{* *} \\
(0.068)\end{array}$ & & $\begin{array}{c}0.245 \\
(0.199)\end{array}$ \\
\hline Polity ${ }^{\star}$ Time until election & & $\begin{array}{l}0.018^{*} \\
(0.009)\end{array}$ & & \\
\hline Anocracy ${ }^{*}$ Time until election & & & & $\begin{array}{l}-0.207 \\
(0.228)\end{array}$ \\
\hline Democracy*Time until election & & & & $\begin{array}{c}0.177 \\
(0.220)\end{array}$ \\
\hline Control variables & & & & \\
\hline Political constraints & $\begin{array}{l}-0.682 \\
(0.520)\end{array}$ & $\begin{array}{l}-0.772 \\
(0.520)\end{array}$ & $\begin{array}{c}-0.988^{*} \\
(0.489)\end{array}$ & $\begin{array}{c}-1.096^{*} \\
(0.492)\end{array}$ \\
\hline $\log (\mathrm{GDP})$ & $\begin{array}{c}-0.094^{*} \\
(0.038)\end{array}$ & $\begin{array}{c}-0.108^{* *} \\
(0.038)\end{array}$ & $\begin{array}{l}-0.062 \\
(0.039)\end{array}$ & $\begin{array}{l}-0.075 \\
(0.040)\end{array}$ \\
\hline$\Delta \mathrm{GDP}$ & $\begin{array}{c}0.060^{* * *} \\
(0.011)\end{array}$ & $\begin{array}{c}0.058^{* * *} \\
(0.011)\end{array}$ & $\begin{array}{c}0.066^{* * *} \\
(0.011)\end{array}$ & $\begin{array}{c}0.063^{* * *} \\
(0.011)\end{array}$ \\
\hline Trade (\% of GDP) & $\begin{array}{c}-0.006^{* *} \\
(0.002)\end{array}$ & $\begin{array}{c}-0.007^{* *} \\
(0.002)\end{array}$ & $\begin{array}{c}-0.006^{* *} \\
(0.002)\end{array}$ & $\begin{array}{c}-0.007^{* *} \\
(0.002)\end{array}$ \\
\hline FDI, net inflows ( $\%$ of GDP) & $\begin{array}{l}-0.005 \\
(0.012)\end{array}$ & $\begin{array}{l}-0.003 \\
(0.012)\end{array}$ & $\begin{array}{c}-0.005 \\
(0.012)\end{array}$ & $\begin{array}{l}-0.004 \\
(0.012)\end{array}$ \\
\hline Natural resource rents (\% of GDP) & $\begin{array}{l}0.016^{*} \\
(0.007)\end{array}$ & $\begin{array}{c}0.014 \\
(0.007)\end{array}$ & $\begin{array}{c}0.023^{* *} \\
(0.008)\end{array}$ & $\begin{array}{c}0.022^{* *} \\
(0.008)\end{array}$ \\
\hline Constant & $\begin{array}{c}-3.206^{* * *} \\
(0.925)\end{array}$ & $\begin{array}{c}-2.642^{* *} \\
(0.953)\end{array}$ & $\begin{array}{c}-4.537^{* * *} \\
(1.001)\end{array}$ & $\begin{array}{c}-3.936^{* * *} \\
(1.044)\end{array}$ \\
\hline$\overline{\mathrm{AIC}}$ & 3170.387 & 3153.374 & 3155.091 & 3135.515 \\
\hline $\mathrm{BIC}$ & 3253.553 & 3255.021 & 3247.497 & 3255.643 \\
\hline Log Likelihood & -1576.194 & -1565.687 & -1567.546 & -1554.757 \\
\hline $\mathrm{N}$ & 76160 & 76160 & 76160 & 76160 \\
\hline
\end{tabular}

Notes: The outcome indicates the number of violations. Standard errors are shown in parentheses $\left({ }^{* * *} p<0.001,{ }^{* *} p<0.01\right.$, $\left.{ }^{*} p<0.05\right)$. In all models, the total number of potential treaty-year observations is 523,035 , though in 446,875 of those there is no BIT present, leaving a total of 76,160 potential violator-years. 
Table A.6: Heckman selection regression estimates.

\begin{tabular}{|c|c|c|}
\hline & \multicolumn{2}{|c|}{ Dependent variable: } \\
\hline & $\begin{array}{l}\text { Treaty in force }(1=\text { Yes }) \\
\text { Selection Equation } \\
(1)\end{array}$ & $\begin{array}{c}\text { Any violations }(1=\text { violations }>0 \\
\text { Outcome Equation } \\
(2)\end{array}$ \\
\hline Anocracy & $\begin{array}{c}-0.274^{* * *} \\
(0.010)\end{array}$ & $\begin{array}{c}0.022^{* * *} \\
(0.004)\end{array}$ \\
\hline Democracy & $\begin{array}{c}-0.306^{* * *} \\
(0.010)\end{array}$ & $\begin{array}{c}0.026^{* * *} \\
(0.004)\end{array}$ \\
\hline Time until election & $\begin{array}{c}0.052^{* * *} \\
(0.003)\end{array}$ & $\begin{array}{c}-0.004^{* * *} \\
(0.001)\end{array}$ \\
\hline Anocracy ${ }^{*}$ Time until election & $\begin{array}{c}-0.033^{* * *} \\
(0.005)\end{array}$ & $\begin{array}{c}0.002^{* *} \\
(0.001)\end{array}$ \\
\hline Democracy ${ }^{*}$ Time until election & $\begin{array}{c}-0.041^{* * *} \\
(0.004)\end{array}$ & $\begin{array}{c}0.004^{* * *} \\
(0.001)\end{array}$ \\
\hline \multicolumn{3}{|l|}{ Control variables } \\
\hline Political constraints & $\begin{array}{c}0.356^{* * *} \\
(0.015)\end{array}$ & $\begin{array}{c}-0.030^{* * *} \\
(0.005)\end{array}$ \\
\hline $\log (\mathrm{GDP})$ & $\begin{array}{c}0.183^{* * *} \\
(0.001)\end{array}$ & $\begin{array}{c}-0.013^{* * *} \\
(0.002)\end{array}$ \\
\hline$\Delta \mathrm{GDP}$ & $\begin{array}{c}0.001 \\
(0.0005)\end{array}$ & $\begin{array}{c}0.0001 \\
(0.0001)\end{array}$ \\
\hline Trade (\% of GDP) & $\begin{array}{l}0.002^{* * *} \\
(0.00005)\end{array}$ & $\begin{array}{c}-0.0002^{* * *} \\
(0.00003)\end{array}$ \\
\hline FDI, net inflows (\% of GDP) & $\begin{array}{c}0.005^{* * *} \\
(0.0003)\end{array}$ & $\begin{array}{c}-0.0003^{* * *} \\
(0.0001)\end{array}$ \\
\hline Natural resource rents (\% of GDP) & $\begin{array}{c}-0.006^{* * *} \\
(0.0002)\end{array}$ & $\begin{array}{c}0.0005^{* * *} \\
(0.0001)\end{array}$ \\
\hline Constant & $\begin{array}{c}-5.577^{* * *} \\
(0.031)\end{array}$ & $\begin{array}{c}0.468^{* * *} \\
(0.086)\end{array}$ \\
\hline $\mathrm{N}$ & 523035 & 76160 \\
\hline
\end{tabular}

Notes: Probit regression coefficients shown with standard errors in parentheses in both models $\left({ }^{* * *} p<0.001,{ }^{* *} p<0.01\right.$, $\left.{ }^{*} p<0.05\right)$. In all models, the total number of potential treaty-year observations is 523,035 , though in 446,875 of those there is no BIT present, leaving a total of 76,160 potential violator-years. 
Table A.7: Logistic regression estimates using ISDS data from Wellhausen 2016.

\begin{tabular}{|c|c|c|c|c|}
\hline & \multicolumn{4}{|c|}{ Dependent variable: } \\
\hline & \multicolumn{4}{|c|}{ Violations } \\
\hline & $(1)$ & $(2)$ & (3) & (4) \\
\hline Polity & $\begin{array}{l}0.033^{*} \\
(0.017)\end{array}$ & $\begin{array}{l}0.046^{*} \\
(0.018)\end{array}$ & & \\
\hline Anocracy & & & $\begin{array}{c}1.015^{* * *} \\
(0.280)\end{array}$ & $\begin{array}{l}0.735^{*} \\
(0.327)\end{array}$ \\
\hline Democracy & & & $1.242^{* * *}$ & $1.349^{* * *}$ \\
\hline Time until election & & $\begin{array}{c}0.195^{* *} \\
(0.065)\end{array}$ & & $\begin{array}{c}0.293 \\
(0.210)\end{array}$ \\
\hline Polity*Time until election & & $\begin{array}{c}0.017 \\
(0.009)\end{array}$ & & \\
\hline & & & $(0.304)$ & $(0.331)$ \\
\hline Anocracy ${ }^{*}$ Time until election & & & & $\begin{array}{c}-0.326 \\
(0.231)\end{array}$ \\
\hline Democracy ${ }^{*}$ Time until election & & & & $\begin{array}{c}0.120 \\
(0.229)\end{array}$ \\
\hline Control variables & & & & \\
\hline Political constraints & $\begin{array}{l}-0.761 \\
(0.491)\end{array}$ & $\begin{array}{l}-0.780 \\
(0.490)\end{array}$ & $\begin{array}{c}-1.136^{*} \\
(0.461)\end{array}$ & $\begin{array}{c}-1.150^{*} \\
(0.464)\end{array}$ \\
\hline $\log (\mathrm{GDP})$ & $\begin{array}{c}-0.093^{* *} \\
(0.035)\end{array}$ & $\begin{array}{c}-0.107^{* *} \\
(0.036)\end{array}$ & $\begin{array}{c}-0.071 \\
(0.037)\end{array}$ & $\begin{array}{c}-0.085^{*} \\
(0.037)\end{array}$ \\
\hline$\Delta \mathrm{GDP}$ & $\begin{array}{c}0.020^{* *} \\
(0.007)\end{array}$ & $\begin{array}{c}0.019^{* *} \\
(0.007)\end{array}$ & $\begin{array}{l}0.016^{*} \\
(0.007)\end{array}$ & $\begin{array}{l}0.017^{*} \\
(0.007)\end{array}$ \\
\hline Trade (\% of GDP) & $\begin{array}{c}-0.005^{*} \\
(0.002)\end{array}$ & $\begin{array}{c}-0.005^{*} \\
(0.002)\end{array}$ & $\begin{array}{c}-0.005^{*} \\
(0.002)\end{array}$ & $\begin{array}{c}-0.006^{* *} \\
(0.002)\end{array}$ \\
\hline FDI, net inflows (\% of GDP) & $\begin{array}{c}0.001 \\
(0.009)\end{array}$ & $\begin{array}{c}0.001 \\
(0.009)\end{array}$ & $\begin{array}{c}0.001 \\
(0.009)\end{array}$ & $\begin{array}{c}0.001 \\
(0.009)\end{array}$ \\
\hline Natural resource rents (\% of GDP) & $\begin{array}{c}0.011 \\
(0.007)\end{array}$ & $\begin{array}{c}0.009 \\
(0.007)\end{array}$ & $\begin{array}{l}0.017^{*} \\
(0.007)\end{array}$ & $\begin{array}{l}0.017^{*} \\
(0.007)\end{array}$ \\
\hline Constant & $\begin{array}{c}-3.172^{* * *} \\
(0.925) \\
\end{array}$ & $\begin{array}{c}-2.584^{* *} \\
(0.953) \\
\end{array}$ & $\begin{array}{c}-4.513^{* * *} \\
(1.001)\end{array}$ & $\begin{array}{c}-3.880^{* * *} \\
(1.044)\end{array}$ \\
\hline$\overline{\mathrm{AIC}}$ & 3014.593 & 2998.084 & 3000.918 & 2979.041 \\
\hline $\mathrm{BIC}$ & 3088.518 & 3090.490 & 3084.084 & 3089.929 \\
\hline Log Likelihood & -1499.297 & -1489.042 & -1491.459 & -1477.521 \\
\hline $\mathrm{N}$ & 76160 & 76160 & 76160 & 76160 \\
\hline
\end{tabular}

Notes: Logistic regression coefficients shown with standard errors in parentheses in both models $\left({ }^{* * *} p<0.001,{ }^{* *} p<0.01\right.$, $\left.{ }^{*} p<0.05\right)$. In all models, the total number of potential treaty-year observations is 523,035 , though in 446,875 of those there is no BIT present, leaving a total of 76,160 potential violator-years. 
Table A.8: Logistic regression, estimates the percent of cases that are actually filed which are lost, ISDS data from Wellhausen 2016.

\begin{tabular}{lc}
\hline \hline & Dependent variable: \\
\cline { 2 - 2 } & Lost cases/Total cases \\
& $(1)$ \\
\hline Polity & $0.049^{*}$ \\
Political contraints & $(0.022)$ \\
& $-1.260^{*}$ \\
log(GDP) & $(0.592)$ \\
& -0.116 \\
GDP & $(0.059)$ \\
Trade $(\%$ of GDP) & 0.013 \\
& $(0.018)$ \\
FDI, net inflows $\%$ of GDP) & $-0.008^{* *}$ \\
& $(0.003)$ \\
Natural resource rents (\% of GDP) & 0.002 \\
& $(0.020)$ \\
Constant & 0.001 \\
& $(0.011)$ \\
AIC & 2.785 \\
LIC & $(1.542)$ \\
\hline \hline
\end{tabular}

Notes: Logistic regression coefficients shown with standard errors in parentheses in both models $\left({ }^{* * *} p<0.001,{ }^{* *} p<0.01\right.$, $\left.{ }^{*} p<0.05\right)$. In all models, the total number of potential treaty-year observations is 394 . 
Figure A.1: Change in the predicted probability of signing a BIT given the interaction between the continuous measure of democracy and time until election.

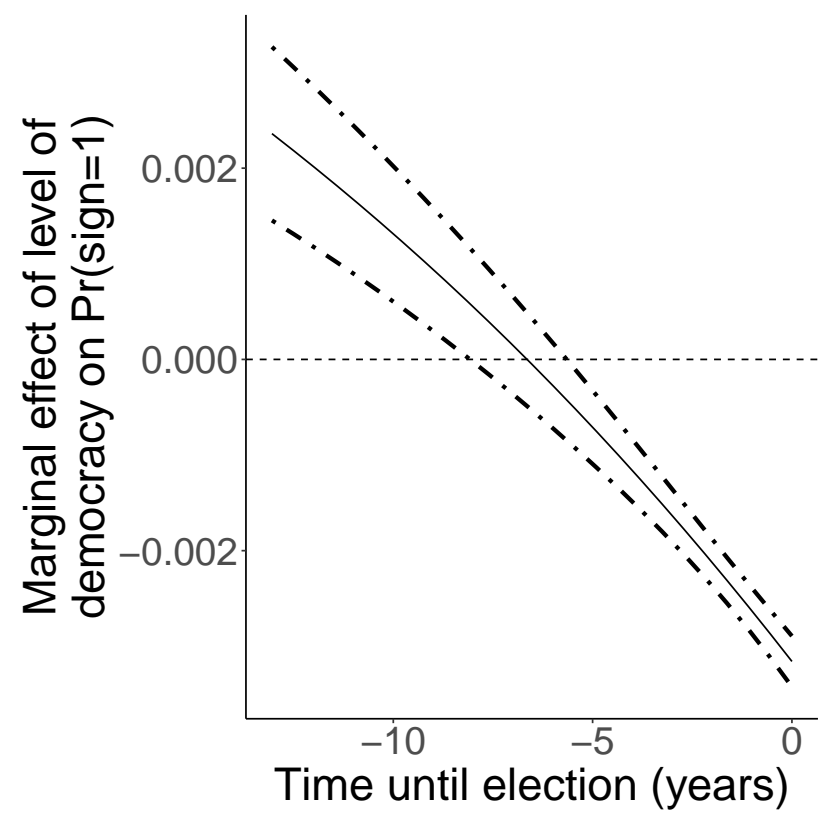

Notes: We cannot estimate the marginal effect as $\hat{\delta}_{1}=\hat{\beta}_{1}+\hat{\beta}_{3} x_{2}$ because the size of $\hat{\delta}_{1}$ does not convey any intuitive interpretation of the size of the effect of a given moderating variable. Therefore, we estimate the change in the predicted probability, $\hat{y}$, given a shift in the moderator, while also varying $x_{2}$ (plotted along the $\mathrm{x}$-axis). $95 \%$ confidence intervals are shown. 
Figure A.2: Change in the predicted probability of violation given the interaction between the continuous measure of democracy and time until election (using ISDS data from Wellhausen (2016)).
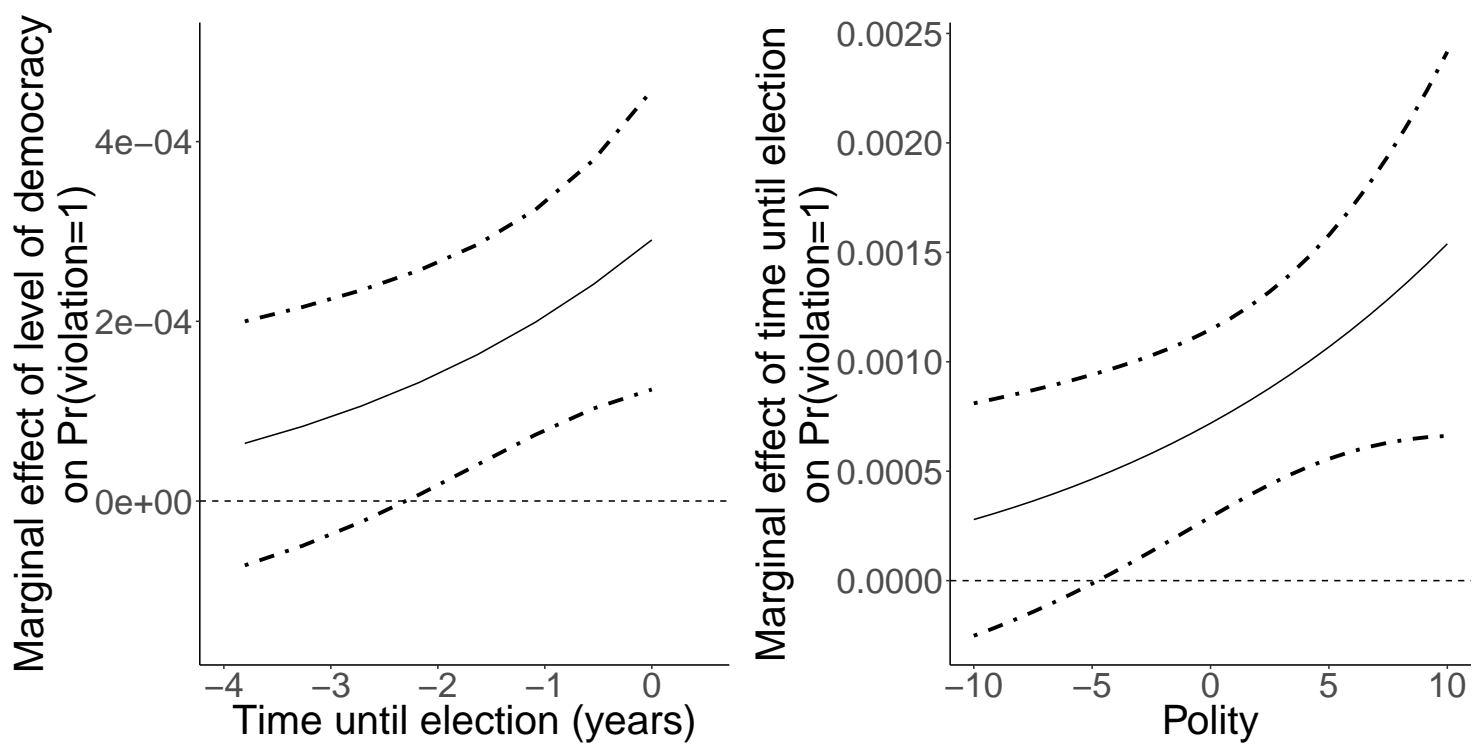

Notes: We cannot estimate the marginal effect as $\hat{\delta}_{1}=\hat{\beta}_{1}+\hat{\beta}_{3} x_{2}$ because the size of $\hat{\delta}_{1}$ does not convey any intuitive interpretation of the size of the effect of a given moderating variable. Therefore, we estimate the change in the predicted probability, $\hat{y}$, given a shift in the moderator, while also varying $x_{2}$ (plotted along the $\mathrm{x}$-axis). $95 \%$ confidence intervals are shown. 
Figure A.3: Missingness in predictors by potential violator from 1990-2013 (Afghanistan through Latvia).
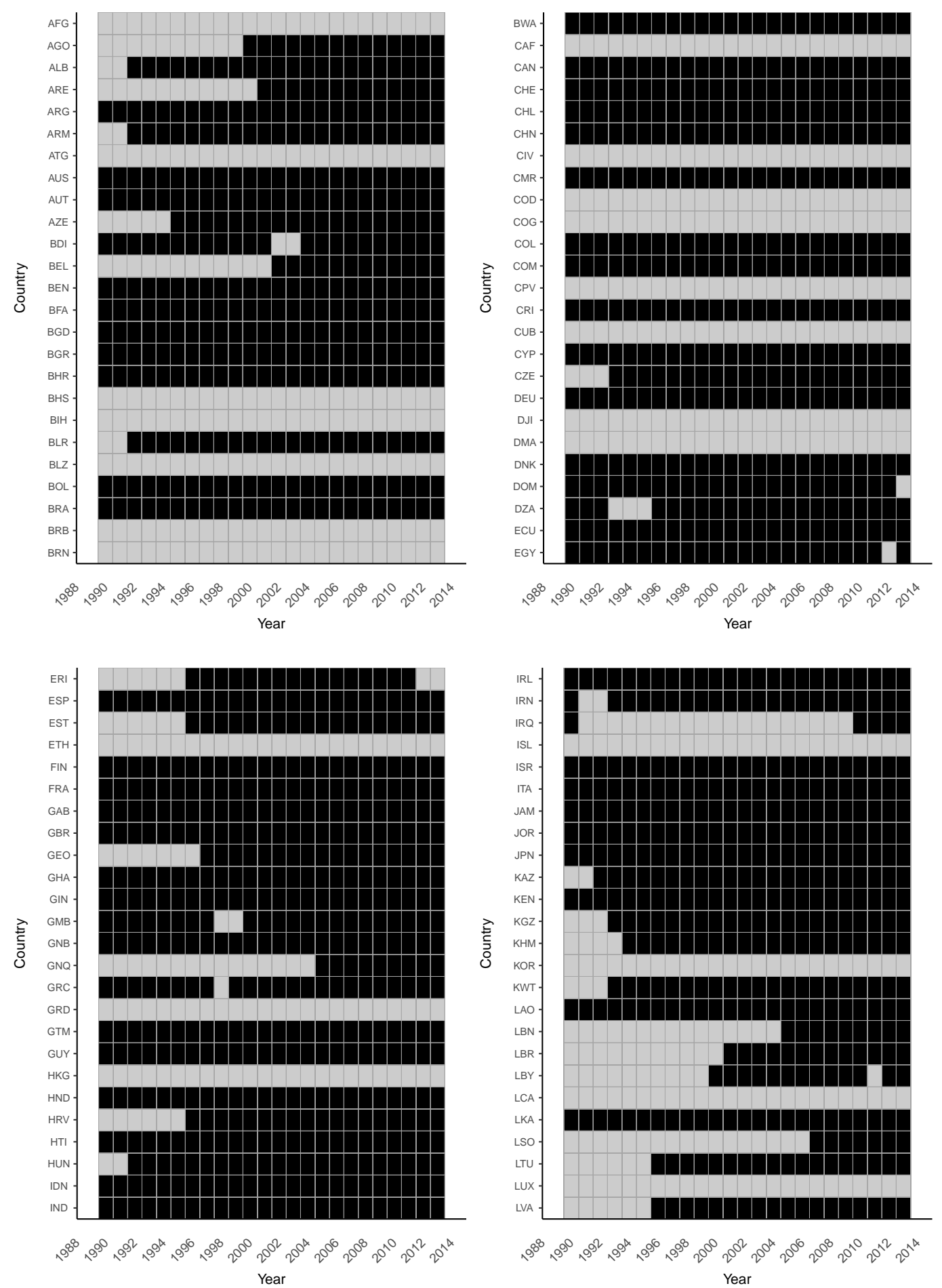

Some missing data Complete cases 
Figure A.4: Missingness in predictors by potential violator from 1990-2013 (Morocco through Zimbabwe).
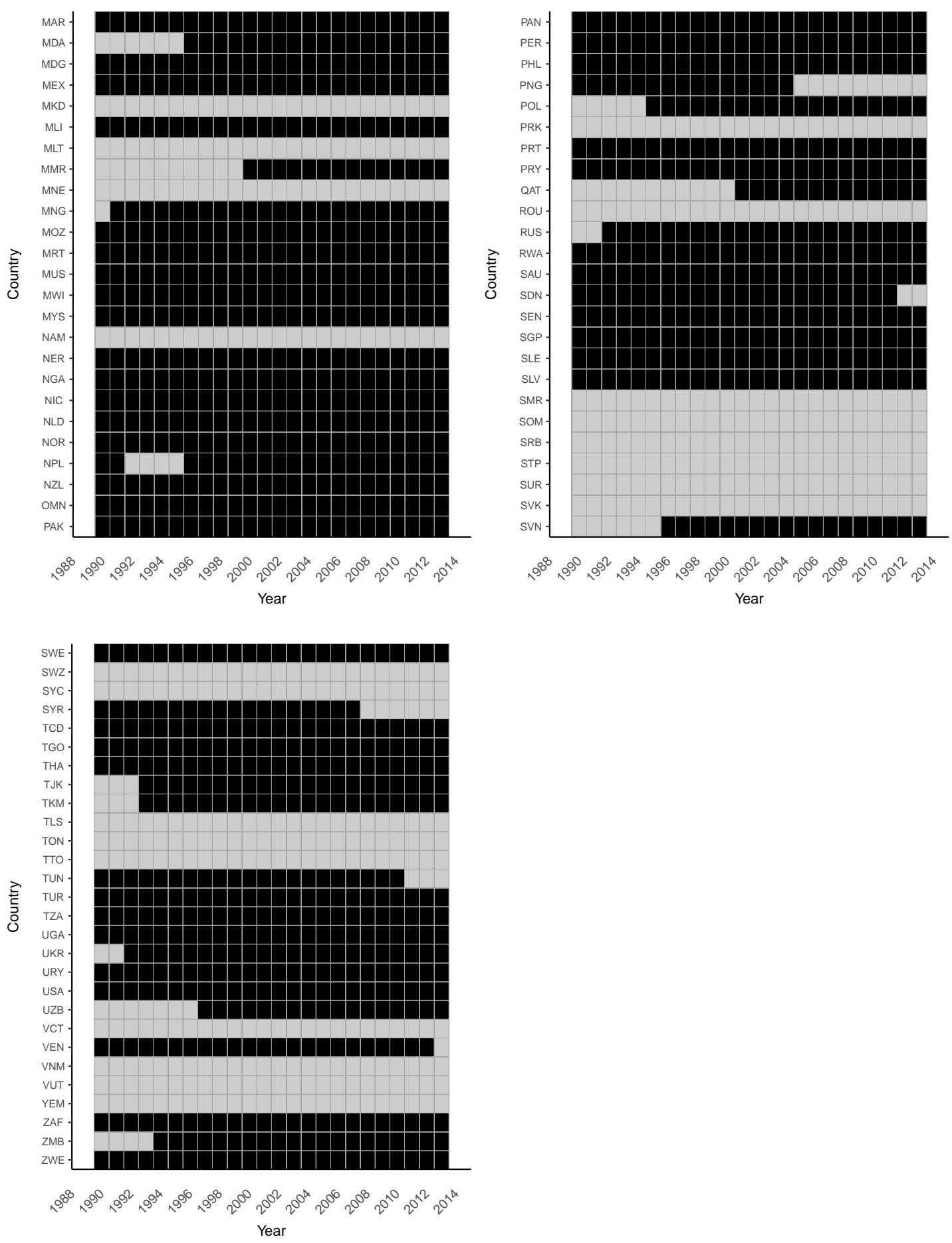
Figure A.5: Distribution of each variable in total data set.
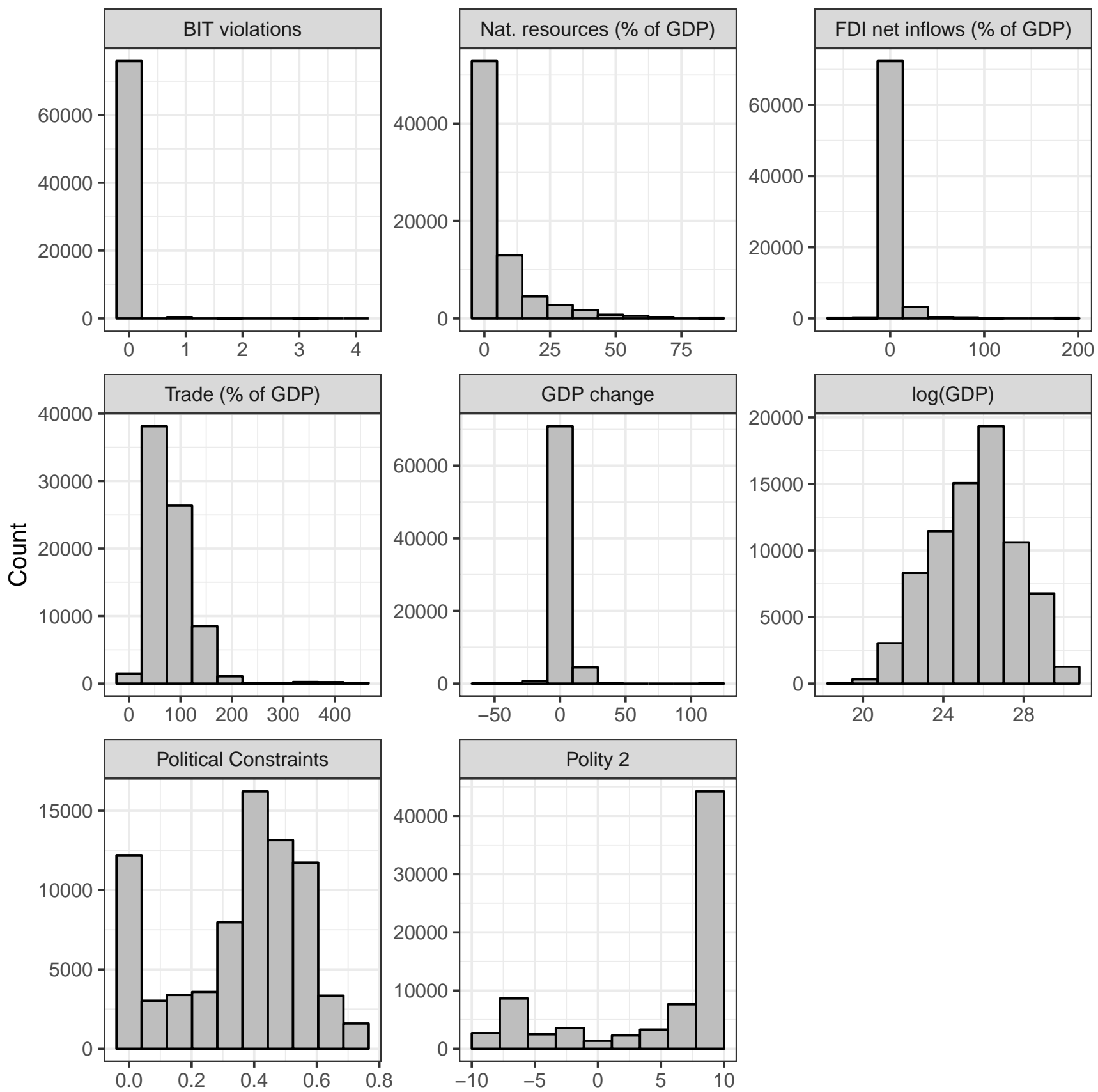

Notes: Though it appears as though there are no violations in the full data set, there are 118 violations. The number of years with no violation are much more frequent (less than $0.4 \%$ of potential violations actually occur). 
Figure A.6: Distribution of each variable by sample.
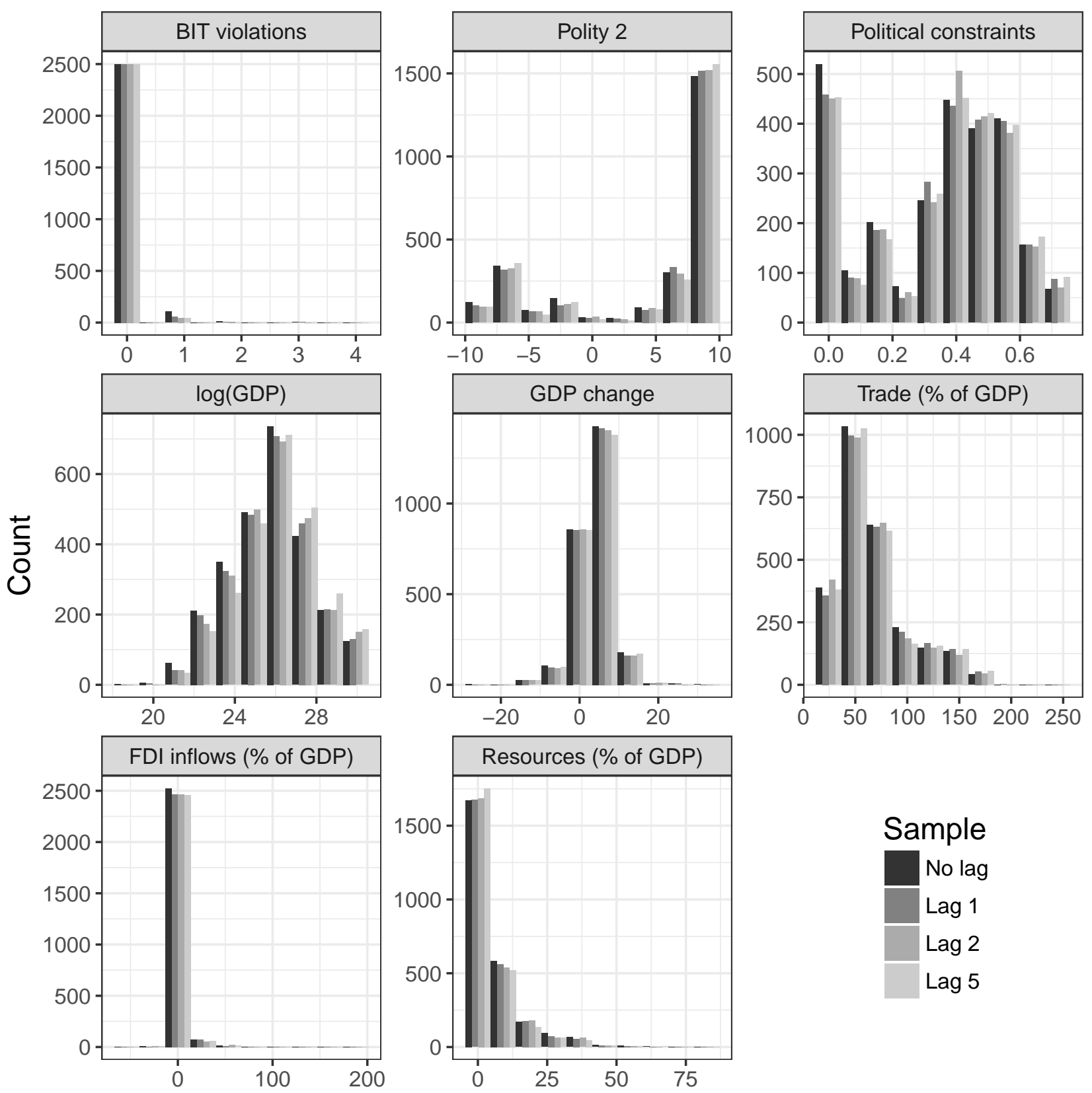